\title{
Quizalofop-p-ethyl Mixed with Synthetic Auxin and ACCase- Inhibiting Herbicides for Weed Management in Rice Production
}

\author{
Eric P. Webster $\mathbb{D}^{1},{ }^{1}$ Samer Y. Rustom Jr., ${ }^{1}$ Benjamin M. McKnight $\mathbb{D}^{1},{ }^{1}$ David C. Blouin, ${ }^{2}$ \\ and Gustavo M. Teló ${ }^{1}$ \\ ${ }^{1}$ Louisiana State University School of Plant, Environmental, and Soil Science, Louisiana State University Agricultural Center, \\ Baton Rouge, LA 70803, USA \\ ${ }^{2}$ Department of Experimental Statistics, Louisiana State University Agricultural Center, Baton Rouge, LA 70803, USA
}

Correspondence should be addressed to Eric P. Webster; ewebster@agcenter.lsu.edu

Received 22 February 2019; Accepted 16 May 2019; Published 10 June 2019

Academic Editor: Patrick J. Tranel

Copyright $\odot 2019$ Eric P. Webster et al. This is an open access article distributed under the Creative Commons Attribution License, which permits unrestricted use, distribution, and reproduction in any medium, provided the original work is properly cited.

A study was conducted near Crowley, Louisiana, to evaluate the efficacy of quizalofop-p-ethyl mixed with different synthetic auxin and ACCase-inhibiting herbicides for barnyardgrass and weedy rice control in rice production systems. Quizalofop was applied at 0 or $120 \mathrm{~g}$ ai ha $^{-1}$ mixed with $2,4-\mathrm{D}$ at $1336 \mathrm{~g}$ ai $\cdot \mathrm{ha}^{-1}$, triclopyr at $282 \mathrm{~g}$ ai $\cdot \mathrm{ha}^{-1}$, quinclorac at $420 \mathrm{~g}$ ai $\cdot$ ha ${ }^{-1}$, cyhalofop-butyl at

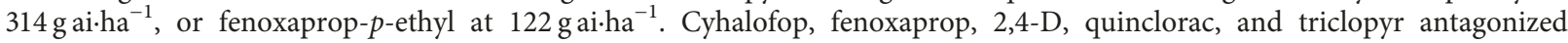
quizalofop for barnyardgrass control at 14 days after treatment (DAT). At 28 DAT, an antagonistic response persisted for barnyardgrass control, except when cyhalofop was mixed with quizalofop, which indicated a neutral response. Red rice, CLXL745 , and CL-111 control decreased due to antagonism of quizalofop when mixed with 2,4-D. However, quinclorac, triclopyr, cyhalofop, or fenoxaprop mixed with quizalofop resulted in a neutral response for red rice, CLXL-745, and CL-111 control at 28 DAT.

\section{Introduction}

Weeds present a constant problem in rice (Oryza sativa L.) production and can reduce rice yield with early season competition $[1,2]$. The lack of weed control can reduce rice yield over 90\%; therefore, effective weed management programs are essential for maximizing rice production $[2,3]$. Red rice and barnyardgrass are among the most common and troublesome weeds of rice production worldwide $[4,5]$. Red rice (Oryza sativa L.) can become the dominant weed in cultivated rice due to its high competitive ability [6, 7]. Found in nearly every rice field, barnyardgrass (Echinochloa crus-galli (L.) P. Beauv.) is another troublesome weed that can significantly reduce rice yields [3].

In 2002, imidazolinone-resistant (IR) rice was introduced for commercial use $[8,9]$. Imazethapyr was the first herbicide labeled for use in IR rice in the U.S., and for the first time, red rice control was possible with a postemergence herbicide application in a conventional rice crop. Imazethapyr provide control of barnyardgrass. However, within a few years of introduction, red rice and barnyardgrass populations were found resistant to imazethapyr $[10,11]$.

BASF developed a new herbicide-resistant rice to be sold under the trade name Provisia ${ }^{\circledR}$. The herbicide labeled for use is quizalofop, also sold under the trade name Provisia ${ }^{\circledR}$ [12]. Quizalofop inhibits acetyl coenzyme A carboxylase (ACCase), with postemergence activity on annual and perennial grass species $[13,14]$. Producers can use ACCaseresistant rice (ACCase-R) to manage weedy rice and other grass species during cultivated rice production [15].

Rotation of herbicides and herbicide mixtures with differing sites of action is important for sustainable rice production. These practices can help manage or slow the development of weed resistance. In order to increase weed control, herbicide mixtures have proven to be beneficial by increasing weed control spectrum, increasing the yield and economic returns [16-20]. Herbicide mixtures may exhibit 
three responses: synergistic, antagonistic, or neutral [15, 21-28]. A neutral response occurs when the observed control is equivalent to the expected control calculated using Colby's response $[15,21,23,24,27,28]$. A synergistic response occurs when the observed control is higher than the predicted value, and antagonism occurs when the observed control is less than the predicted control.

Mixing quizalofop with synthetic auxin herbicides can increase the weed control spectrum, because the auxin herbicides have broad-spectrum activity on dicot and/or grass weeds [29, 30]. The auxin mechanism of action affects protein synthesis, cell division, and growth and stimulates ethylene evolution in plants [31]. Previous research has indicated ACCase-inhibiting herbicide activity can be antagonized when mixed with another herbicide [15, 32]. Antagonism interactions were reported when diclofop-methyl was mixed with 2,4-D, resulting in a decrease in foliar absorption of diclofop [30]. Consequently, synthetic auxin herbicides mixed with ACCase-inhibiting herbicides can reduce herbicide translocation from treated leaves to shoot and root meristems [33].

The mixture of two ACCase-inhibiting herbicides is another option. These mixtures can broaden the spectrum of control for annual and perennial grass weeds; however, the potential for antagonism exists [34, 35]. A prepackage mixture of fluazifop and fenoxaprop is commercially available for use in cotton (Gossypium hirsutum L.) and soybean (Glycine max L.) [36]. Previous research reported synergism with a mixture of two ACCase herbicides, fluazifop plus sethoxydim, for control of annual grass weeds [37], and the ACCase-inhibiting herbicides have shown activity on lipid biosynthesis and auxin-induced growth [38]. Therefore, understanding mixture interactions of quizalofop with auxin activity herbicides or with other ACCase-inhibiting herbicides is important for developing an approach for weed management utilizing the new ACCase- $\mathrm{R}$ rice technology. The objective of this research was to evaluate the interactions of quizalofop-p-ethyl when mixed with synthetic auxin or other ACCase-inhibiting herbicides for weed management in ACCase- $\mathrm{R}$ rice production.

\section{Materials and Methods}

2.1. Field Research Site and Herbicide Application. A field study was conducted at the LSU AgCenter H. Rouse Caffey Rice Research Station (RRS) near Crowley, Louisiana $\left(30.177147^{\circ} \mathrm{N},-92.347743^{\circ} \mathrm{W}\right)$, in 2015 and 2016 . The soil type at the RRS is a Crowley silt loam with a $\mathrm{pH}$ of 6.4 and $1.4 \%$ organic matter. Soil preparation consisted of a fall and spring disking followed by two operations in opposite directions with a two-way bed conditioner consisting of rolling baskets and S-tine harrows set at $6 \mathrm{~cm}$ depth.

Plot size was 5.1 by $1.5 \mathrm{~m}$, with eight- $19.5 \mathrm{~cm}$ drill-seeded rows planted as follows: 4 center rows of ACCase-R "PVL01" long grain rice, 2 rows of inbred IR "CL-111" long grain rice, and 2 outside rows of IR "CLXL-745" hybrid long grain rice. PVL01, CL-111, and CLXL-745 were each planted at a rate of
$70 \mathrm{~kg} \cdot \mathrm{ha}^{-1}$. Awnless straw-hull red rice was broadcast at $50 \mathrm{~kg} \cdot \mathrm{ha}^{-1}$ across the research area prior to drill seeding rice. The hybrid, inbred, and red rice represent a weedy rice population. The research area was naturally infested with barnyardgrass. The area was surface irrigated to a depth of $5 \mathrm{~cm}$ for $24 \mathrm{~h}$ after planting, and irrigation water was held for $24 \mathrm{~h}$ to allow for soil saturation.

A permanent $10 \mathrm{~cm}$ flood was established when ACCase$\mathrm{R}$ rice reached the four- to five-leaf stage and was maintained until three weeks prior to harvest. Herbicides were applied $24 \mathrm{~h}$ after permanent flood with a $\mathrm{CO}_{2}$-pressurized backpack sprayer calibrated at $145 \mathrm{kPa}$ to deliver $140 \mathrm{~L} \cdot \mathrm{ha}^{-1}$ with five flat-fan 110015 nozzles spaced at $35 \mathrm{~cm}$. Red rice, CLXL-745, and CL-111 were at the four-leaf to one-tiller growth stage, and barnyardgrass was in the three-leaf to one-tiller growth stage. Barnyardgrass and red rice populations were 100 to 125 plants $\mathrm{m}^{2}$ at herbicide application.

\subsection{Plot Design Herbicide Rates and Application Timing.} The study was a randomized complete block with a factorial arrangement of treatments with four replications. Factor A consisted of quizalofop applied at $120 \mathrm{~g}$ ai $\cdot \mathrm{ha}^{-1}$ or no qui-

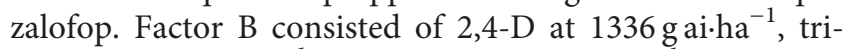
clopyr at $282 \mathrm{~g}$ ai $\cdot \mathrm{ha}^{-1}$, quinclorac at $420 \mathrm{~g}$ ai $\cdot \mathrm{ha}^{-1}$, cyhalofopbutyl at $314 \mathrm{~g}$ ai $\cdot \mathrm{ha}^{-1}$, fenoxaprop-p-ethyl at $122 \mathrm{~g}$ ai $\cdot \mathrm{ha}^{-1}$, or no mixture herbicide. Source of materials is listed in Table 1. A second application of quizalofop was applied across the entire research area at a rate of $120 \mathrm{~g} \cdot \mathrm{ha}^{-1}$ at 28 days after the initial quizalofop treatment in an effort to salvage rice yield. A crop oil concentrate was added to each herbicide application at a rate of $1 \% \mathrm{v} / \mathrm{v}$.

\subsection{Rice Injury and Weed Control Evaluation. Visual eval-} uations for this study included crop injury of PVL01 and control of barnyardgrass, red rice, CLXL-745, and CL-111. Control and crop injury were recorded as percentages, with $0 \%=$ no control or no crop injury and $100 \%=$ complete plant death at 14 and 28 days after treatment (DAT). ACCase- $\mathrm{R}$ rice plant height was recorded from four plants in each plot measured from the ground to the tip of the extended rice panicle, at harvest maturity.

2.4. Data Analysis. Data were analyzed using the Blouin et al. [21] augmented mixed model to determine synergistic, antagonistic, or neutral responses for herbicide mixtures by comparing an expected control which is calculated based on activity of each herbicide applied alone to an observed control $[15,23,24,27,28]$. The fixed effects for all models were the herbicide treatments and evaluation timing. The random effects were year, replication within year, and plot. Considering year or combination of years as a random effect accounts for different environmental conditions each year having an effect on herbicide treatments for that year $[39,40]$. Normality of effects over all DAT was checked using the UNIVARIATE [41]. Significant normality problems were not observed. 
TABLE 1: Source of materials.

\begin{tabular}{lcccc}
\hline $\begin{array}{l}\text { Herbicide common } \\
\text { name }\end{array}$ & Herbicide trade name & Concentration $\left(\mathrm{g} \mathrm{ai} \mathrm{L}^{-1}\right)$ & Formulation & Manufacturer \\
\hline 2,4-D & Opti-amine & 454 & $\mathrm{~L}$ & Helena Chemical Company, Collierville, TN \\
Cyhalofop-butyl & Clincher SF & 285 & EC & Dow AgroSciences LLC, Indianapolis, IN \\
Fenoxaprop-p-ethyl & Ricestar HT & 70 & EC & Bayer Crop Protection LLC, Greensboro, NC \\
Quinclorac & Facet L & 180 & EC & BASF Corporation, Research Triangle Park, NC \\
$\begin{array}{l}\text { Quizalofop } \\
\text { Triclopyr }\end{array}$ & Provisia & 105 & EC & BASF Corporation, Research Triangle Park, NC \\
\hline
\end{tabular}

\section{Results and Discussion}

\subsection{Herbicide Interactions Observed for Weed Control}

3.1.1. Herbicide Interactions Observed for Barnyardgrass Control. An antagonistic response was observed for barnyardgrass treated with 2,4-D, quinclorac, triclopyr, cyhalofop, or fenoxaprop mixed with quizalofop at 14 DAT (Table 2). The addition of $2,4-\mathrm{D}$ in a quizalofop mixture reduced barnyardgrass control to $24 \%$ compared with control of 77 to $86 \%$ for barnyardgrass treated with all other mixtures evaluated. At 28 DAT, cyhalofop mixed with quizalofop resulted in a neutral response with $97 \%$ control of barnyardgrass. However, all other mixtures evaluated resulted in antagonism of quizalofop for barnyardgrass control. Like quizalofop, cyhalofop is an ACCase-inhibiting (Group 1) herbicide with activity on barnyardgrass, and when mixed with quizalofop, the potential for antagonism may be reduced. However, fenoxaprop is also an ACCase inhibitor (Group 1) and antagonism was observed when mixed with quizalofop with $90 \%$ observed control compared with an expected control of $99 \%$.

Barnyardgrass treated with 2,4-D mixed with quizalofop resulted in an antagonistic response and did not exceed 5\% control at $28 \mathrm{DAT}$, compared with an expected control of 98\% (Table 2). Previous research indicates a similar response of 2,4-D amine antagonism of quizalofop for control of volunteer wheat (Triticum aestivum L.) [42] and is similar to research evaluating ACCase-inhibiting herbicides mixed with dicot herbicides $[15,32]$.

3.1.2. Herbicide Interactions Observed for Red Rice, CLXL745, and CL-111 Control. Red rice treated with quizalofop plus 2,4-D resulted in an antagonistic response at 14 and 28 DAT (Table 3). The observed control of red rice with 2,4-D mixed with quizalofop was $51 \%$ at 14 DAT compared with an expected control of $94 \%$ and $37 \%$ control at 28 DAT compared with an expected control of $99 \%$. A neutral response was observed with quizalofop plus quinclorac, triclopyr, cyhalofop, or fenoxaprop for red rice control across all evaluation dates. The neutral responses observed resulted in red rice control of 93 to $98 \%$ at 28 DAT, compared with the expected control of $99 \%$.

Similar results were observed for CLXL-745 hybrid rice control compared with red rice (Table 4). A neutral response was observed for CLXL-745 when treated with quizalofop plus quinclorac, triclopyr, cyhalofop, or fenoxaprop at both evaluation dates. As with red rice, an antagonistic response was observed with 2,4-D mixed with quizalofop resulting in an observed control of $41 \%$, compared with an expected control of $91 \%$ at 14 DAT. At 28 DAT, CLXL-745 treated with quizalofop plus 2,4-D was controlled $37 \%$ compared with an expected control of $98 \%$, resulting in severe antagonism of quizalofop.

Control of CL-111 was similar to red rice and CLXL745. Quizalofop was only antagonized when mixed with 2,4-D at 14 and 28 DAT, and these results are similar to those reported by others for cultivated oat (Avena sativa L.) and wild oat (Avena fatua L.) control [30, 33]. A neutral response was observed for CL-111 control with all other herbicides mixed with quizalofop at both evaluation dates (Table 5). An application of 2,4-D mixed with quizalofop resulted in an observed control of 42 and $38 \%$ at 14 and 28 DAT, respectively, compared with an expected control of 95 to $98 \%$.

\subsection{PVL01 ACCase-Resistant Rice Response to Herbicide} Treatment. No injury was observed on PVL01 across both evaluation dates (data not shown). PVL01 rice plant height was not influenced by any herbicide combination evaluated (data not shown).

The initial herbicide applications were applied following establishment of the permanent flood when PVL01 rice was in the later tillering stage, because 2,4-D should be applied at this timing to avoid rice crop injury. As previously discussed, a second quizalofop application was made in an effort to salvage rice yield; however, early season weed competition from planting through permanent flood establishment resulted in little to no PVL01 rice grain available for harvest (data not shown).

\section{Conclusion}

The addition of 2,4-D, quinclorac, triclopyr, or fenoxaprop antagonized quizalofop activity for barnyardgrass control. Antagonism was observed at 14 DAT with the quizalofop plus cyhalofop mixture, however, by $28 \mathrm{DAT}$ a neutral response occurred. This neutral response indicates the potential for this mixture in an ACCase- $\mathrm{R}$ rice production system, but a mixture with the same site of action may not be advisable in a resistant management program.

Red rice, CLXL-745, and CL-111 control indicated antagonism of quizalofop when applied in a mixture with 2,4D. However, quinclorac, triclopyr, cyhalofop, or fenoxaprop mixed with quizalofop resulted in a neutral response for red 
TABLE 2: Barnyardgrass control with quizalofop- $p$-ethyl mixed with different synthetic auxin or ACCase-inhibiting herbicides in 2015 and 2016 crop seasons.

\begin{tabular}{|c|c|c|c|c|c|}
\hline \multirow{3}{*}{ Mixture herbicide $^{\mathrm{a}}$} & \multirow{3}{*}{ Rate $\left(\right.$ g ai $\mathrm{ha}^{-1}$ ) } & \multicolumn{3}{|c|}{ Quizalofop (g ai $\cdot \mathrm{ha}^{-1}$ ) } & \multirow{3}{*}{$P$ value $^{\mathrm{c}}$} \\
\hline & & \multirow{2}{*}{$\begin{array}{c}0 \\
\text { Observed }\end{array}$} & \multicolumn{2}{|c|}{120} & \\
\hline & & & $\begin{array}{l}\text { Expected } \\
\% \text { Control }\end{array}$ & Observed $^{\mathrm{b}}$ & \\
\hline \multicolumn{6}{|l|}{$14 \mathrm{DAT}$} \\
\hline None & - & 0 & - & 91 & - \\
\hline $2,4-\mathrm{D}$ & 1336 & 0 & 91 & $24-$ & 0.0001 \\
\hline Quinclorac & 420 & 42 & 95 & $77-$ & 0.0001 \\
\hline Triclopyr & 282 & 0 & 91 & $79-$ & 0.0001 \\
\hline Cyhalofop-butyl & 314 & 75 & 98 & $86-$ & 0.0001 \\
\hline Fenoxaprop-p-ethyl & 122 & 72 & 98 & $85-$ & 0.0001 \\
\hline \multicolumn{6}{|l|}{$28 \mathrm{DAT}$} \\
\hline None & - & 0 & - & 98 & - \\
\hline $2,4-\mathrm{D}$ & 1336 & 36 & 98 & $5-$ & 0.0001 \\
\hline Quinclorac & 420 & 59 & 99 & $86-$ & 0.0001 \\
\hline Triclopyr & 282 & 39 & 98 & $91-$ & 0.0046 \\
\hline Cyhalofop-butyl & 314 & 85 & 99 & 97 & 0.1126 \\
\hline Fenoxaprop-p-ethyl & 122 & 75 & 99 & $90-$ & 0.0001 \\
\hline
\end{tabular}

${ }^{\mathrm{a}}$ Evaluation date and respective herbicide mixture. DAT, days after treatment. ${ }^{\mathrm{b}}$ Observed means followed by a plus $(+)$ or a minus $(-)$ are significantly different from Blouin's modified Colby's expected responses at the $5 \%$ level indicating a synergistic or an antagonistic response. No $(+)$ or $(-)$ indicates a neutral response. ${ }^{\mathrm{c}} P<0.05$ indicates antagonistic response; $P>0.05$ indicates an additive response.

TABLE 3: Red rice control with quizalofop-p-ethyl mixed with different synthetic auxin or ACCase-inhibiting herbicides in 2015 and 2016 crop seasons.

\begin{tabular}{|c|c|c|c|c|c|}
\hline \multirow{3}{*}{ Mixture herbicide $^{a}$} & \multirow{3}{*}{ Rate $\left(\mathrm{g}\right.$ ai $\left.\cdot \mathrm{ha}^{-1}\right)$} & \multicolumn{3}{|c|}{ Quizalofop (gai.ha ${ }^{-1}$ ) } & \multirow{3}{*}{$P$ value } \\
\hline & & \multirow{2}{*}{$\begin{array}{c}0 \\
\text { Observed }\end{array}$} & \multicolumn{2}{|c|}{120} & \\
\hline & & & $\begin{array}{l}\text { Expected } \\
\% \text { Control }\end{array}$ & Observed $^{\mathrm{b}}$ & \\
\hline \multicolumn{6}{|l|}{$14 \mathrm{DAT}$} \\
\hline None & - & 0 & - & 94 & - \\
\hline $2,4-\mathrm{D}$ & 1336 & 0 & 94 & $51-$ & 0.0001 \\
\hline Quinclorac & 420 & 0 & 94 & 85 & 0.0799 \\
\hline Triclopyr & 282 & 0 & 94 & 85 & 0.1079 \\
\hline Cyhalofop-butyl & 314 & 0 & 94 & 88 & 0.2710 \\
\hline Fenoxaprop-p-ethyl & 122 & 0 & 94 & 86 & 0.1188 \\
\hline \multicolumn{6}{|l|}{$28 \mathrm{DAT}^{1}$} \\
\hline None & - & 0 & - & 99 & - \\
\hline $2,4-\mathrm{D}$ & 1336 & 0 & 99 & $37-$ & 0.0001 \\
\hline Quinclorac & 420 & 0 & 99 & 96 & 0.6405 \\
\hline Triclopyr & 282 & 0 & 99 & 93 & 0.3031 \\
\hline Cyhalofop-butyl & 314 & 0 & 99 & 98 & 0.8440 \\
\hline Fenoxaprop-p-ethyl & 122 & 0 & 99 & 94 & 0.3770 \\
\hline
\end{tabular}

${ }^{a}$ Evaluation date and respective herbicide mixture. DAT, days after treatment. ${ }^{b}$ Observed means followed by a plus $(+)$ or a minus $(-)$ are significantly different from Blouin's modified Colby's expected responses at the $5 \%$ level indicating a synergistic or an antagonistic response. No $(+)$ or $(-)$ indicates a neutral response. ${ }^{c} P<0.05$ indicates antagonistic response; $P>0.05$ indicates an additive response.

TABLE 4: Hybrid rice CLXL-745 IR control with quizalofop-p-ethyl mixed with different synthetic auxin or ACCase-inhibiting herbicides in 2015 and 2016 crop seasons.

\begin{tabular}{|c|c|c|c|c|c|}
\hline \multirow{3}{*}{ Mixture herbicide $^{\mathrm{a}}$} & \multirow{3}{*}{ Rate $\left(\mathrm{g}\right.$ ai $\left.\cdot \mathrm{ha}^{-1}\right)$} & \multicolumn{3}{|c|}{ Quizalofop (g ai.ha ${ }^{-1}$ ) } & \multirow{3}{*}{$P$ value } \\
\hline & & \multirow{2}{*}{$\begin{array}{c}0 \\
\text { Observed }\end{array}$} & \multicolumn{2}{|c|}{120} & \\
\hline & & & $\begin{array}{l}\text { Expected } \\
\% \text { Control }\end{array}$ & Observed $^{\mathrm{b}}$ & \\
\hline \multicolumn{6}{|l|}{$14 \mathrm{DAT}$} \\
\hline None & - & 0 & - & 91 & - \\
\hline $2,4-\mathrm{D}$ & 1336 & 0 & 91 & $41-$ & 0.0001 \\
\hline Quinclorac & 420 & 0 & 91 & 84 & 0.2454 \\
\hline
\end{tabular}


TABLE 4: Continued.

\begin{tabular}{|c|c|c|c|c|c|}
\hline \multirow{3}{*}{ Mixture herbicide $^{\mathrm{a}}$} & \multirow{3}{*}{ Rate $\left(\right.$ g ai $\left.\mathrm{ha}^{-1}\right)$} & \multicolumn{3}{|c|}{ Quizalofop (g ai $\cdot \mathrm{ha}^{-1}$ ) } & \multirow{3}{*}{$P$ value $^{\mathrm{c}}$} \\
\hline & & \multirow{2}{*}{$\begin{array}{c}0 \\
\text { Observed }\end{array}$} & \multicolumn{2}{|c|}{120} & \\
\hline & & & $\begin{array}{l}\text { Expected } \\
\% \text { Control }\end{array}$ & Observed $^{\mathrm{b}}$ & \\
\hline Triclopyr & 282 & 0 & 91 & 85 & 0.2735 \\
\hline Cyhalofop-butyl & 314 & 0 & 91 & 87 & 0.5016 \\
\hline Fenoxaprop-p-ethyl & 122 & 0 & 91 & 84 & 0.2454 \\
\hline \multicolumn{6}{|l|}{$28 \mathrm{DAT}$} \\
\hline None & - & 0 & - & 98 & - \\
\hline $2,4-\mathrm{D}$ & 1336 & 0 & 98 & $37-$ & 0.0001 \\
\hline Quinclorac & 420 & 0 & 98 & 95 & 0.6690 \\
\hline Triclopyr & 282 & 0 & 98 & 93 & 0.3810 \\
\hline Cyhalofop-butyl & 314 & 0 & 98 & 97 & 0.9282 \\
\hline Fenoxaprop-p-ethyl & 122 & 0 & 98 & 96 & 0.7527 \\
\hline
\end{tabular}

${ }^{\mathrm{a}}$ Evaluation date and respective herbicide mixture. DAT, days after treatment. ${ }^{\mathrm{b}}$ Observed means followed by a plus $(+)$ or a minus $(-)$ are significantly different from Blouin's modified Colby's expected responses at the 5\% level indicating a synergistic or an antagonistic response. No $(+)$ or $(-)$ indicates a neutral response. ${ }^{c} P<0.05$ indicates antagonistic response; $P>0.05$ indicates an additive response.

TABLE 5: CL-111 IR rice control with quizalofop-p-ethyl mixed with different synthetic auxin or ACCase-inhibiting herbicides in 2015 and 2016 crop seasons.

\begin{tabular}{|c|c|c|c|c|c|}
\hline \multirow{3}{*}{ Mixture herbicide ${ }^{a}$} & \multirow{3}{*}{ Rate $\left(\right.$ g ai $\cdot \mathrm{ha}^{-1}$ ) } & \multicolumn{3}{|c|}{ Quizalofop (g ai $\cdot \mathrm{ha}^{-1}$ ) } & \multirow{3}{*}{$P$ value ${ }^{c}$} \\
\hline & & \multirow{2}{*}{$\begin{array}{c}0 \\
\text { Observed }\end{array}$} & \multicolumn{2}{|c|}{120} & \\
\hline & & & $\begin{array}{l}\text { Expected } \\
\% \text { control }\end{array}$ & Observed $^{\mathrm{b}}$ & \\
\hline \multicolumn{6}{|l|}{$14 \mathrm{DAT}$} \\
\hline None & - & 0 & - & 95 & - \\
\hline $2,4-\mathrm{D}$ & 1336 & 0 & 94 & $42-$ & 0.0001 \\
\hline Quinclorac & 420 & 0 & 94 & 84 & 0.0640 \\
\hline Triclopyr & 282 & 0 & 94 & 84 & 0.0607 \\
\hline Cyhalofop-butyl & 314 & 0 & 94 & 87 & 0.1974 \\
\hline Fenoxaprop-p-ethyl & 122 & 0 & 94 & 84 & 0.0640 \\
\hline \multicolumn{6}{|l|}{$28 \mathrm{DAT}$} \\
\hline None & - & 0 & - & 98 & - \\
\hline $2,4-\mathrm{D}$ & 1336 & 0 & 98 & $38-$ & 0.0000 \\
\hline Quinclorac & 420 & 0 & 98 & 94 & 0.3881 \\
\hline Triclopyr & 282 & 0 & 98 & 94 & 0.4014 \\
\hline Cyhalofop-butyl & 314 & 0 & 98 & 97 & 0.9044 \\
\hline Fenoxaprop-p-ethyl & 122 & 0 & 98 & 96 & 0.6831 \\
\hline
\end{tabular}

${ }^{a}$ Evaluation date and respective herbicide mixture. DAT, days after treatment. ${ }^{\mathrm{b}}$ Observed means followed by a plus (+) or a minus $(-)$ are significantly different from Blouin's modified Colby's expected responses at the $5 \%$ level indicating a synergistic or an antagonistic response. No $(+)$ or $(-)$ indicates a neutral response. ${ }^{c} P<0.05$ indicates antagonistic response; $P>0.05$ indicates an additive response.

rice and CLXL-745 control across both evaluation dates. These data indicate potential herbicide mixtures that can be used in ACCase-R rice to help broaden the weed control spectrum. However, caution should be taken when mixing quizalofop with other ACCase-inhibiting herbicides, because this mixture does not meet the standards for a resistance management program. As with any resistance management program, multiple applications of herbicides with different sites of action may prevent or delay the development of herbicide-resistant weeds. In ACCase- $\mathrm{R}$ rice production, producers should overlay herbicides with residual activity early in the growing season followed by two postemergence applications of quizalofop in combination with herbicides that control dicot weeds $[15,43]$.

\section{Data Availability}

The data used to support the findings of this study are available from the corresponding author upon request.

\section{Conflicts of Interest}

The authors declare that there are no conflicts of interest regarding the publication of this paper.

\section{Acknowledgments}

This article is published with the approval of the Director of the Louisiana Agricultural Experiment Station, Louisiana 
State University Agricultural Center, Baton Rouge, LA 70803, under manuscript number 2019-306-33610. Funding for this research project was provided by the Louisiana Rice Research Board.

\section{References}

[1] D. Y. Lanclos, E. P. Webster, W. Zhang, and S. D. Linscombe, "Response of glufosinate-resistant rice (Oryza sativa) to glufosinate application timings," Weed Technology, vol. 17, no. 1, pp. 157-160, 2003.

[2] W. Zhang, E. P. Webster, D. Y. Lanclos, and J. P. Geaghan, "Effect of weed interference duration and weed-free period on glufosinate-resistant rice (Oryza sativa)," Weed Technology, vol. 17, no. 4, pp. 876-880, 2003.

[3] R. J. Smith Jr, "Weed competition in rice," Weed Science, vol. 16, no. 2, pp. 252-255, 1968.

[4] L. E. Estorninos, D. R. Gealy, E. E. Gbur, R. E. Talbert, and M. R. McClelland, "Rice and red rice interference. II. Rice response to population densities of three red rice (Oryza sativa) ecotypes," Weed Science, vol. 53, no. 5, pp. 683-689, 2005.

[5] D. R. Gealy, E. J. Wailes, L. E. Estorninos, and R. S. C. Chavez, "Rice cultivar differences in suppression of barnyardgrass (Echinochloa crus-galli) and economics of reduced propanil rates," Weed Science, vol. 51, no. 4, pp. 601-609, 2003.

[6] A. Andres, S. Fogliatto, A. Ferrero, and F. Vidotto, "Growth variability of Italian weedy rice populations grown with or without cultivated rice," Crop Science, vol. 55, no. 1, pp. 394-402, 2015.

[7] R. J. Smith Jr., "Weed thresholds in southern U.S. rice, Oryza sativa," Weed Technology, vol. 2, no. 3, pp. 232-241, 1988.

[8] Anonymous, Newpath ${ }^{\circledR}$ Herbicide Product Label, BASF Corporation Publication No. 241-412, Research Triangle Park, NC, USA, 2018.

[9] T. P. Croughan, "Clearfield rice: it's not a GMO," Louisiana Agriculture, vol. 46, pp. 24-6, 2003.

[10] D. S. Riar, J. K. Norsworthy, V. Srivastava, V. Nandula, J. A. Bond, and R. C. Scott, "Physiological and molecular basis of acetolactate synthase-inhibiting herbicide resistance in barnyardgrass (Echinochloa crus-galli)," Journal of Agricultural and Food Chemistry, vol. 61, no. 2, pp. 278-289, 2013.

[11] F. O. Matzenbacher, A. Kalsing, V. G. Menezes, J. A. N. Barcelos, and A. Merotto Jr., "Rapid diagnosis of resistance to imidazolinone herbicides in barnyardgrass (Echinochloa crus-galli) and control of resistant biotypes with alternative herbicides," Planta Daninha, vol. 33, no. 3, pp. 645-656, 2013.

[12] Anonymous, Provisia ${ }^{\circledR}$ Herbicide Product Label, BASF Corporation Publication No. 2017-04-522-0004, Research Triangle Park, NC, USA, 2018.

[13] J. D. Burton, J. W. Gronwald, D. A. Somers, B. G. Gengenbach, and D. L. Wyse, "Inhibition of corn acetylCoA carboxylase by cyclohexanedione and aryloxyphenoxypropionate herbicides," Pesticide Biochemistry and Physiology, vol. 34, no. 1, pp. 76-85, 1989.

[14] M. Focke and H. K. Lichtenthaler, "Inhibition of the acetylCoA carboxylase of barley chloroplasts by cycloxydim and sethoxydim," Zeitschrift für Naturforschung C, vol. 42, no. 1112, pp. 1361-1363, 1987.

[15] S. Y. Rustom, E. P. Webster, D. C. Blouin, and B. M. McKnight, "Interactions between quizalofop-p-ethyl and acetolactate synthase-inhibiting herbicides in acetyl-coA carboxylase inhibitor-resistant rice production," Weed Technology, vol. 32, no. 3, pp. 297-303, 2018.

[16] T. P. Carlson, E. P. Webster, M. E. Salassi, J. B. Hensley, and D. C. Blouin, "Imazethapyr plus propanil programs in imidazolinone-resistant rice," Weed Technology, vol. 25, no. 2, pp. 205-211, 2011.

[17] A. Merotto Jr., M. Jasieniuk, and A. J. Fischer, "Estimating the outcrossing rate of Cyperus difformis using resistance to ALSinhibiting herbicides and molecular markers," Weed Research, vol. 49, no. 1, pp. 29-36, 2009.

[18] K. J. Pellerin, E. P. Webster, W. Zhang, and D. C. Blouin, "Herbicide mixtures in water-seeded imidazolinone-resistant rice (Oryza sativa)," Weed Technology, vol. 17, no. 4, pp. 836-841, 2003.

[19] E. P. Webster, T. P. Carlson, M. E. Salassi, J. B. Hensley, and D. C. Blouin, "Imazethapyr plus residual herbicide programs for imidazolinone-resistant rice," Weed Technology, vol. 26, no. 3, pp. 410-416, 2012.

[20] W. Zhang, E. P. Webster, D. C. Blouin, and C. T. Leon, "Fenoxaprop interactions for barnyardgrass (Echinochloa crus-galli) control in rice," Weed Technology, vol. 19, no. 2, pp. 293-297, 2005.

[21] D. C. Blouin, E. P. Webster, and J. A. Bond, "On a method of analysis for synergistic and antagonistic joint-action effects with fenoxaprop mixtures in rice (Oryza sativa)," Weed Technology, vol. 24, no. 4, pp. 583-589, 2010.

[22] S. R. Colby, "Calculating synergistic and antagonistic responses of herbicide combinations," Weeds, vol. 15, no. 1, pp. 20-22, 1967.

[23] J. C. Fish, E. P. Webster, D. C. Blouin, and J. A. Bond, "Imazethapyr co-application interactions in imidazolinoneresistant rice," Weed Technology, vol. 29, no. 4, pp. 689-696, 2015.

[24] J. C. Fish, E. P. Webster, D. C. Blouin, and J. A. Bond, "Imazamox plus propanil mixtures for grass weed management in imidazolinone-resistant rice," Weed Technology, vol. 30, no. 1, pp. 29-35, 2016.

[25] K. K. Hatzios and D. Penner, "Interactions of herbicides with other agrochemicals in higher plants," Reviews of Weed Science, vol. 1, pp. 1-63, 1985.

[26] J. C. Streibig, P. Kudsk, and J. E. Jensen, "A general joint action model for herbicide mixtures," Pesticide Science, vol. 53, no. 1, pp. 21-28, 1998.

[27] E. P. Webster, G. M. Teló, D. C. Blouin, B. M. McKnight, and E. A. Bergeron, "Synergism with imazamox co-applications for red rice control," Weed Technology, vol. 31, no. 3, pp. 373-379, 2017.

[28] E. P. Webster, G. M. Teló, D. C. Blouin, and B. M. McKnight, "Imazethapyr plus propanil mixtures in imidazolinoneresistant rice," Weed Technology, vol. 32, no. 1, pp. 45-51, 2018.

[29] P. H. Dernoeden and M. A. Fidanza, "Fenoxaprop activity influenced by auxin-like herbicide application timing," HortScience, vol. 29, no. 12, pp. 1518-1519, 1994.

[30] B. Kafiz, J. P. Caussanel, R. Scalla, and P. Gaillardon, "Interaction between diclofop-methyl and 2,4-D in wild oat (Avena fatua L.) and cultivated oat (Avena sativa L.), and fate of diclofop-methyl in cultivated oat," Weed Research, vol. 29, no. 4, pp. 299-305, 1989.

[31] K. Grossmann, "Auxin herbicides: current status of mechanism and mode of action," Pest Management Science, vol. 66, no. 2, pp. 113-120, 2009. 
[32] P. Barnwell and A. H. Cobb, "Graminicide antagonism by broadleaf weed herbicides," Pesticide Science, vol. 41, no. 2, pp. 77-85, 1994.

[33] B. G. Todd and E. H. Stobbe, "The basis of the antagonistic effect of 2,4-D on diclofop-methyl toxicity to wild oat (Avena fatua)," Weed Science, vol. 28, no. 4, pp. 371-377, 1980.

[34] B. J. Incledon and J. C. Hall, "Acetyl-coenzyme A carboxylase: quaternary structure and inhibition by graminicidal herbicides," Pesticide Biochemistry and Physiology, vol. 57, no. 3, pp. 255-271, 1997.

[35] D. A. Wall, "Fluazifop-P tank-mixtures with clethodim for annual grass control in flax (Linum usitatissimum)," Weed Technology, vol. 8, no. 4, pp. 673-678, 1994.

[36] Anonymous, Fusion ${ }^{\circledR}$ Herbicide Product Label, Syngenta Crop Protection SCP 1059A-L1D 1213 334497, Greensboro, NC, USA, 2019.

[37] K. N. Harker and P. A. O’Sullivan, "Synergistic mixtures of sethoxydim and fluazifop on annual grass weeds," Weed Technology, vol. 5, no. 2, pp. 310-316, 1991.

[38] H. H. Hoppe, "Effect of diclofop-methyl on protein nucleic acid and lipid biosynthesis in tips of radicles from Zea mays L," Zeitschrift für Pflanzenphysiologie, vol. 102, no. 3, pp. 189-197, 1981.

[39] S. G. Carmer, W. E. Nyquist, and W. M. Walker, "Least significant differences for combined analyses of experiments with two- or three-factor treatment designs," Agronomy Journal, vol. 81, no. 4, pp. 665-672, 1989.

[40] A. G. Hager, L. M. Wax, G. A. Bollero, and E. W. Stoller, "Influence of diphenylether herbicide application rate and timing on common waterhemp (Amaranthus rudis) control in soybean (Glycine max.)," Weed Technology, vol. 17, no. 1, pp. 14-20, 2003.

[41] SAS Institute, Base SAS 9.4 Procedures Guide, SAS Institute, Cary, NC, USA, 2013.

[42] R. E. Blackshaw, K. N. Harker, G. W. Clayton, and J. T. O’Donovan, "Broadleaf herbicide effects on clethodim and quizalofop-p efficacy on volunteer wheat (Triticum aestivum),"Weed Technology, vol. 20, no. 1, pp. 221-226, 2006.

[43] M. J. Osterholt, E. P. Webster, D. C. Blouin, and B. M. McKnight, "Overlay of residual herbicides in rice for improved weed management," Weed Technology, vol. 33, 3 pages, 2019. 


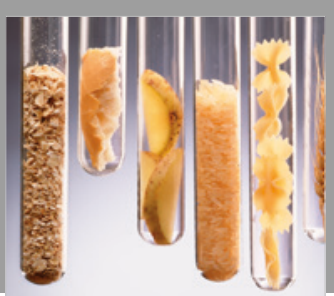

International Journal of Food Science

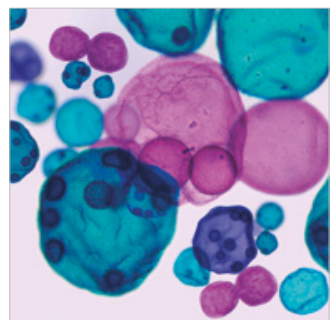

International Journal of Microbiology
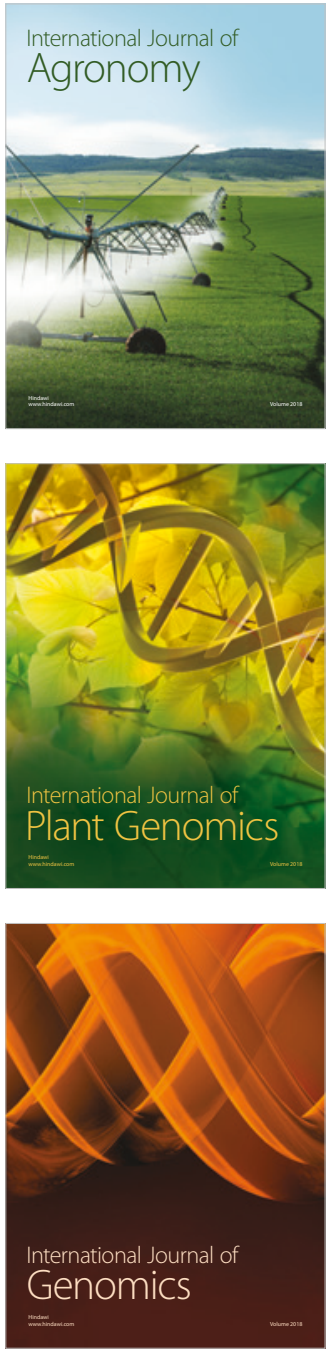

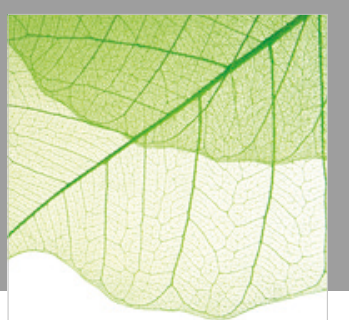

Journal of Botany
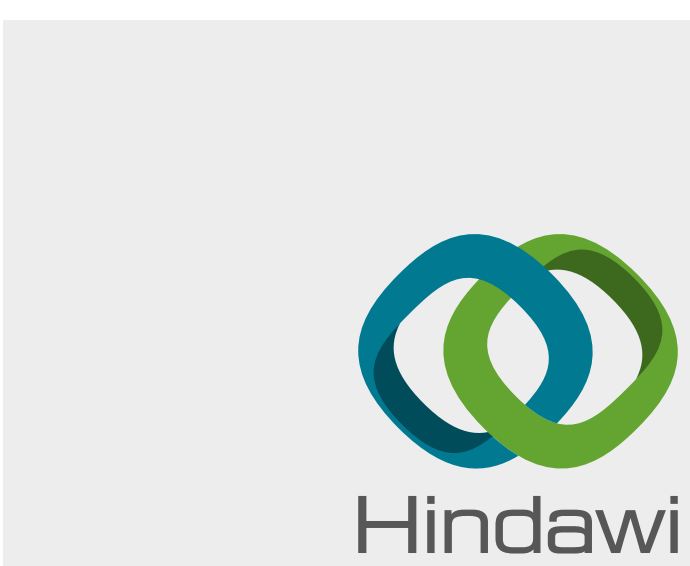

Submit your manuscripts at

www.hindawi.com
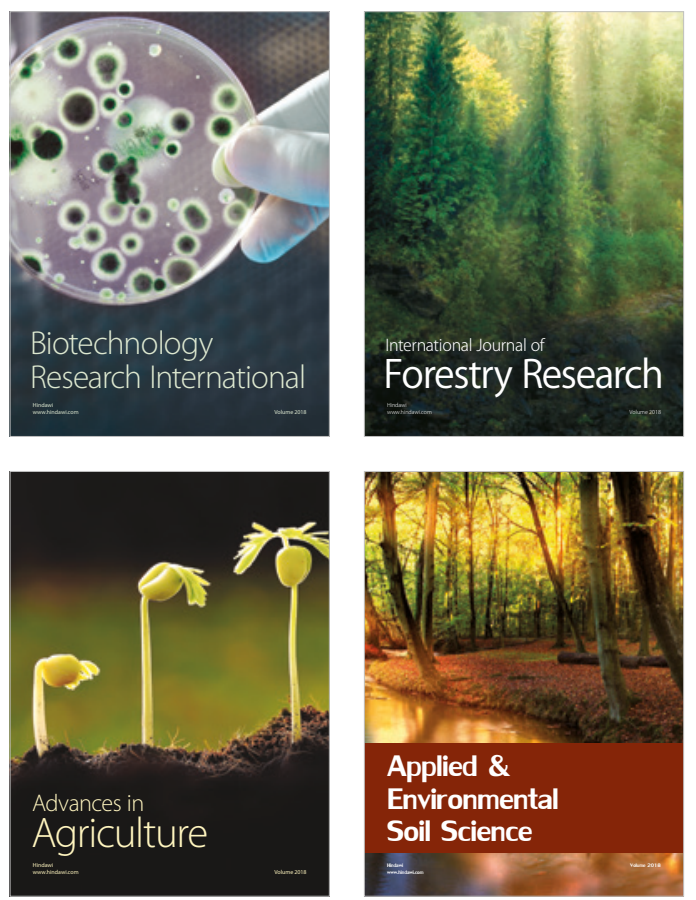

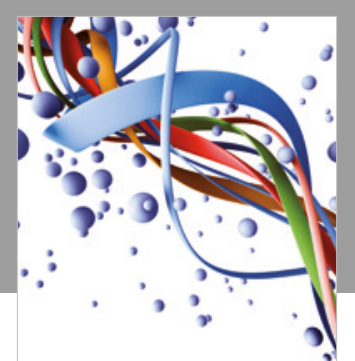

Scientifica

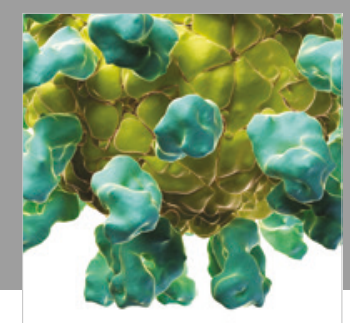

Veterinary Medicine International

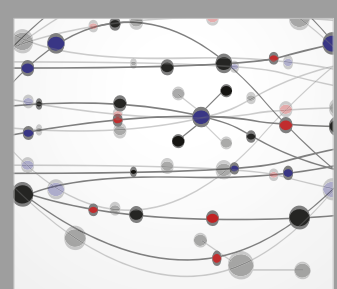

The Scientific World Journal
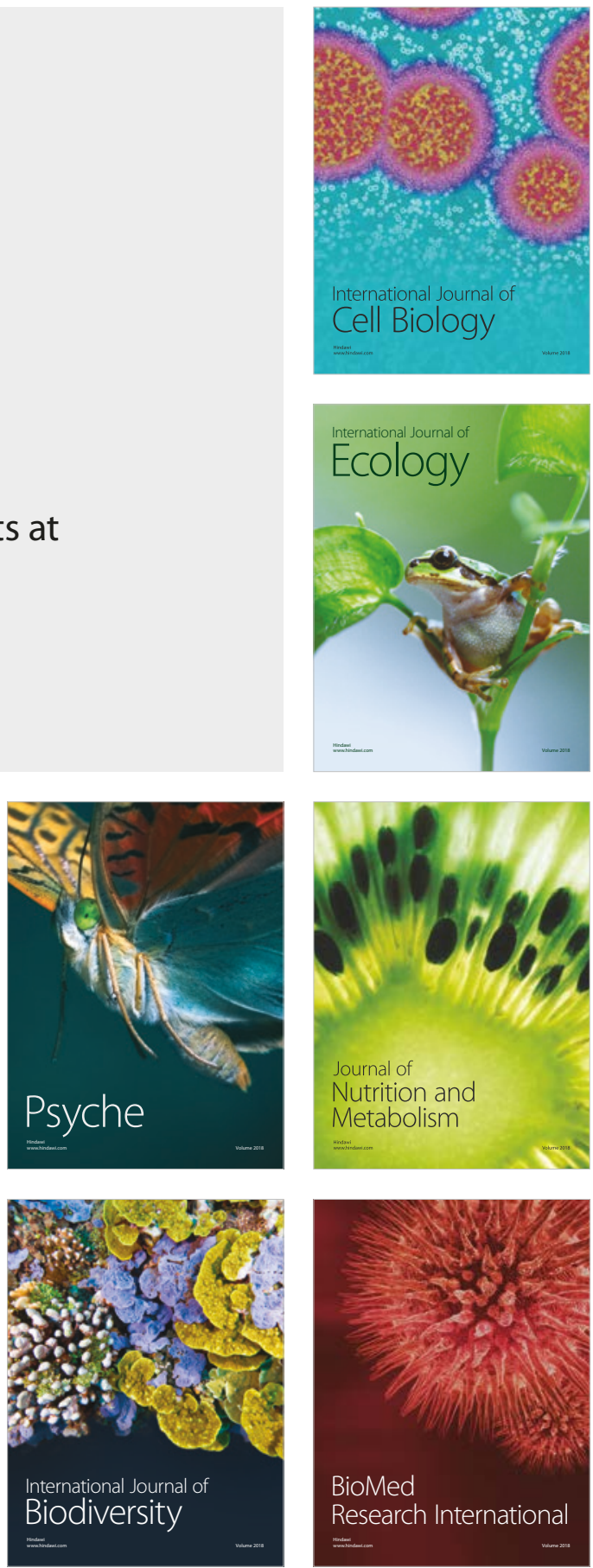